\title{
Heat-waves and Mortality in Czech Cities: A Case Study for the Summers of 2015 and 2016
}

\author{
Daniela Arsenović ${ }^{A^{*}}$, Michal Lehnert ${ }^{B}$, David Fiedor ${ }^{C}$, Petr Šimáček ${ }^{B}$, \\ Hana Středová $D, E$, Tomáš Středa ${ }^{D, E}$, Stevan Savić ${ }^{A}$ \\ Received: July 30, 2019 | Revised: September 22, 2019 | Accepted: September 24, 2019 \\ DOI: $10.5937 / g p 23-22853$
}

\begin{abstract}
The aim of this paper was to assess the impact of heat-waves on mortality in ten Czech cities, using data recorded during the summers of 2015 and 2016. Temperature-related mortality during heat-waves was investigated by comparing mortality figures on heat-wave days and those on other days by means of the Mann-Whitney $U$ test. Results for all-cause mortality, cardiovascular and respiratory diseases $(C V D+R)$ mortality, as well as for mortality in the over-65 age group, show statistically significant differences $(p<0.05)$ during heat-waves compared with other days in seven of ten cities investigated. The effect of heat-waves on mortality did not reach statistical significance in Olomouc, Plzeň and Liberec. The results suggest that further studies addressing spatial patterns of mortality during heat-waves in urban areas are required to assess the vulnerability of the urban populations in particular cities and types of neighbourhood.
\end{abstract}

Keywords: Heat-wave; urban population; temperature-related mortality; Czech Republic

\section{Introduction}

Global climate change presents a growing health risk in several regions worldwide (IPCC, 2014). This is especially true of the central European region, where the increasing frequency and magnitude of heatwaves has attracted a considerable body of research (Ballester et al., 2009; Kyselý, 2009; Christidis et al., 2015; Bobvos et al., 2017). Heat-waves were responsible for $67 \%$ of all natural-hazard-related mortalities in Europe in the 1980-2013 period (EEA, 2017) and further increases in heat-related mortality are antic- ipated (Huang et al., 2011; Paci, 2014; Li et al., 2015; Bobvos at al., 2017). At the same time, the Czech Republic (more recently, Czechia), together with other countries, has undertaken to take measures to reduce the number of fatalities attributable to natural disasters (including heat-waves), within the Sendai framework. Heat-waves are also recognized as major threats to national environmental security (MŽP, 2015). Studies that address the effects on heat-waves on mortality and population health in Czechia, and the central Eu-

A Climatology and Hydrology Research Center, Faculty of Sciences, University of Novi Sad, Trg Dositeja Obradovića 3, 21000 Novi Sad, Serbia, daniela.arsenovic@dgt.uns.ac.rs, stevan.savic@dgt.uns.ac.rs

B Department of Geography, Faculty of Sciences, Palacký University, 17. listopadu 12, 77147 Olomouc, Czech Republic, m.lehnert@upol.cz; petr.simacek@upol.cz

c Department of Sociology, Andragogy, and Cultural Anthropology, Faculty of Arts, Palacký University, Tř. Svobody 8, 77147 Olomouc, Czech Republic, david.fiedor@upol.cz

D Faculty of AgriSciences, Mendel University in Brno, Zemědělská 1665/1, 61300 Brno, Czech Republic, hana.stredova@mendelu. cz, tomas.streda@mendelu.cz

E Department of Meteorology and Climatology, Czech Hydrometeorological Institute, Brno Branch, Kroftova 43, 61667 Brno, Czech Republic

* Corresponding author: Daniela Arsenović, e-mail: daniela.arsenovic@dgt.uns.ac.rs 
ropean region in general, have therefore taken on new and pressing importance.

A number of studies relevant to heat-related mortality have been published in the past two decades. The summer heat-wave of 2003 stimulated a substantial body of research, since most of the countries in western Europe were affected by it, with an estimated 70,000 related deaths (Robine et al., 2008). Nearly 15,000 excess deaths were recorded in France alone (Fouillet et al., 2006), constituting some 54\% of total excess mortality in the country (Le Tertre et al., 2006); disparities in excess mortality rates varied from $+4 \%$ in Lille to $+142 \%$ in Paris (Vandentorren et al., 2004). In Switzerland, the 2003 heat-wave was responsible for a $6.9 \%$ increase in all-cause mortality (Grize et al., 2005). Similar relations between heat and mortality were confirmed in eight Swiss cities between 1995 and 2003. In terms of population vulnerability, the 2003 heat-wave was also recognized in Italy, where excess deaths ranged from $+14 \%$ in Bologna to $+33 \%$ in $\mathrm{Tu}-$ rin (Michelozzi et al., 2005). In general, all available studies indicate increases in mortality during heartwave periods, although there is a marked degree of geographical heterogeneity (D’Ippoliti et al., 2010).

Among studies in the central European region, Bobvos et al. (2015) recorded a mortality increase of $30 \%$ in Hungary during the heat-wave that affected south-eastern Europe and parts of central Europe in 2007. During the same heat-wave, Bogdanović et al. (2013) noted $38 \%$ excess mortality in Belgrade (Serbia). Further, Vyberčki et al. (2015) investigated heat-related mortality in Slovakia and pointed out overall increases in mortality during heat-waves for the 1996-2012 period. In selected years, e.g. in 2010, they found an increase in total mortality of $13.6 \%$ compared to anticipated "normal" levels; in summer 2012, to cite another example, the equivalent figure was $13 \%$. Later, Vyberčki et al. (2018) described a 14\% mortality increase during the Slovakian heat-wave of summer 2015. In the Czech Republic, Vysoudil et al. (2016) recorded a substantial increase in mortality when daily maximum temperatures reached $35^{\circ} \mathrm{C}$ in the city of Olomouc and its surroundings. Hutter et al. (2007) and Muthers et al. (2010) calculated a $13 \%$ increase in mortality during periods of extreme heat stress in Vienna (Austria). Graczyk et al. (2018) investigated the impact of heat-waves on mortality in Polish cities over the past three decades and disclosed mortality increases relating to hot days, with the highest additional number of deaths in cities located in areas exhibiting the highest anomalies of air temperature. They also noted that residents of cities with more than 500,000 inhabitants are the most vulnerable.

In Czechia, much of the important research into temperature-related mortality has been conducted by research groups associated with J. Kyselý of the Institute of Atmosperic physics of the Czech Academy of Sciences (Kyselý \& Huth, 2004; Kyselý et al., 2009; Urban \& Kyselý, 2014; Urban et al., 2016; Urban et al., 2019). Kyselý (2003) described an overall mortality increase of $16 \%$ and in specifically cardiovascular mortality of 18\% during the extreme heat-wave of 1994. An analysis performed by Kyselý and Huth (2004) showed a binomial distribution of days with the highest excess morality over the course of the year. They marked periods in which excess deaths departed most from a baseline established in winter and early spring. During heat-waves, there occurred a relative increase of more than $30 \%$ in deviation of mortality from baseline. Further investigation was conducted to compare heat-related mortality in various Czech regions. A study conducted by Urban et al. (2016) addressed differences between urban and rural areas, pointing out the significant influence of the level of urbanization on excess mortality during hot days.

To build upon the important findings of previous studies that have addressed a number of factors relating to mortality during extreme heat events, and pointing out increased vulnerability for the inhabitants of many urbanized areas, additional analysis is required to deepen insight into the particularities of heat-wave- related mortality in Czech cities. This paper presents a case study analyzing the impacts of heat-waves on mortality in the ten largest Czech cities over the course of two summers (2015 and 2016) that differ substantially in their seasonal temperature course and heat-wave occurrence.

\section{Study area}

The ten largest Czech cities, populated by over or close to 100,000 inhabitants, were investigated (Figure 1). These cities together contain $25.4 \%$ of the population of Czechia (CZSO, 2016). However, they differ substantially in size, geography, climate, urban structure and demography (Tables 1, 2). Prague, the county's capital, located on a plateau divided by the distinctive River Vltava valley, is by far the largest of them.
Its already warm climate is further supplemented by a considerable urban heat island (UHI) effect - several degrees Celsius (Beranová \& Huth, 2003; Geletič et al., 2018). Czechia's second-largest city, Brno, is located largely in a basin position, while some parts to the north and west lie in a hilly region. The climate of Brno is warm and a UHI effect of up to $5^{\circ} \mathrm{C}$ has been established (Dobrovolný \& Krahula, 2015). Os- 
trava, Czechia's third-largest city, is located in the eastern part of the country, largely in a basin position with a warm climate. Ostrava is of a predominantly industrial character, in which the quality of life is adversely affected by poor air quality (Jirik et al., 2016). With the changes in industrial requirements and legislation pursuant to the enormous political upheaval of the 1990s, Ostrava has become a typical example of a shrinking city. Plzen is a medium-sized city located in the western part of the Czechia in a basin position, with a moderate climate. Industry has prospered in Plzeň in recent decades, accompanied by urban sprawl and a resulting high percentage of impervious surfaces (Kopp et al., 2015). Liberec is a medium-sized city in the northern part of Czechia, located on a narrow plateau surrounded by mountains, with a moderately warm climate. It remains, however the coolest among the cities studied. Olomouc is a university city located in a flat basin; a moderate UHI effect there, around $2^{\circ} \mathrm{C}$, has been established (Lehnert et al., 2018). České Budějovice is a compact historical city in the southern part of Czechia, located in an elevated basin with a moderately warm climate. Ústí nad Labem lies in the northern part of Czechia, partly following

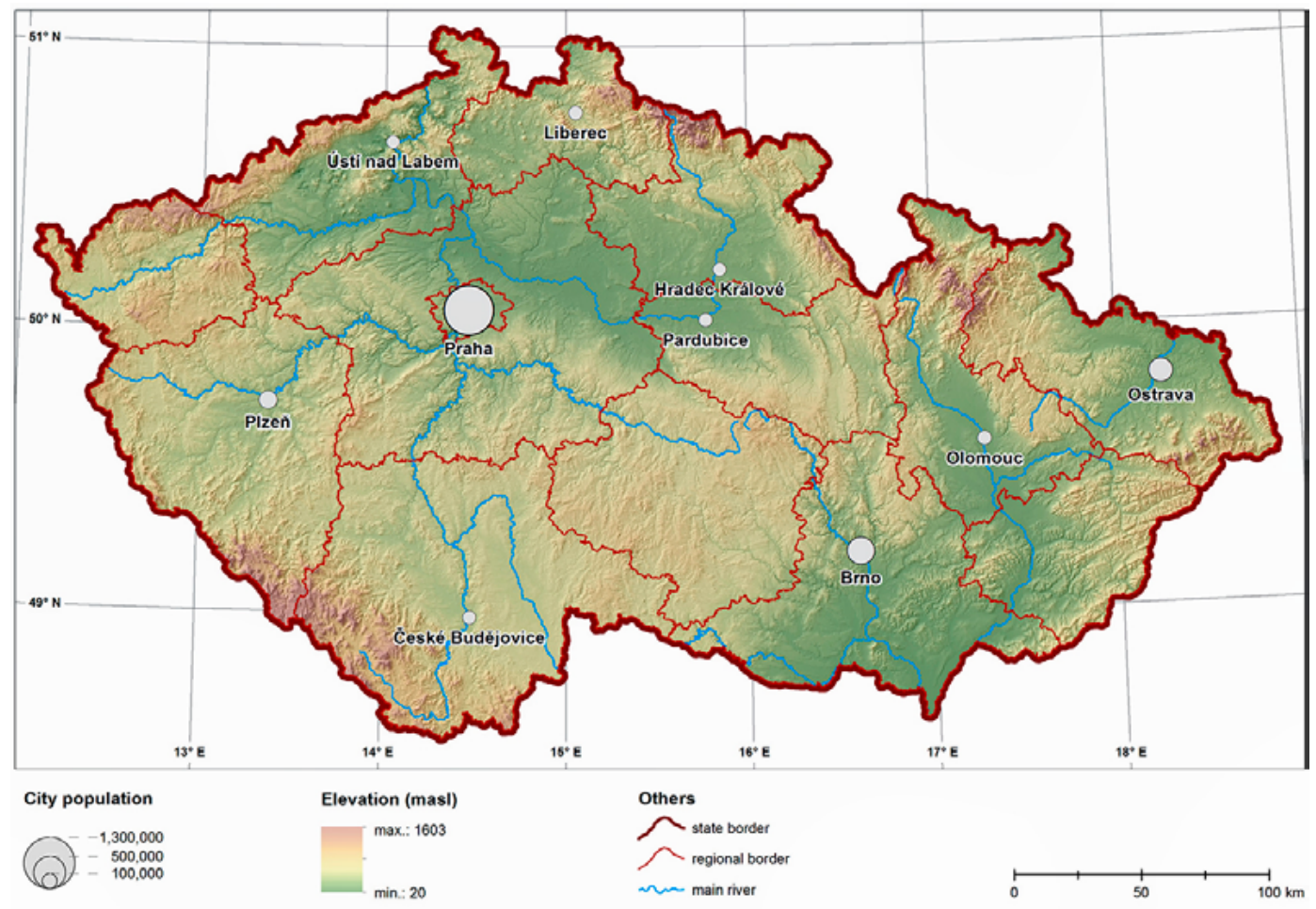

Figure 1. Cities within the territory of Czechia appearing in this study Sources: ArCČR 2016; authors' processing

Table 1. Basic population structures of the cities studied

\begin{tabular}{|l|c|c|c|c|c|c|}
\hline City & $\begin{array}{c}\text { Population } \\
(\mathbf{1 . 1 . 2 0 1 6})\end{array}$ & $\begin{array}{c}\text { Age 65+[\%] } \\
(\mathbf{1 . 1 . 2 0 1 6})\end{array}$ & $\begin{array}{c}\text { All-cause } \\
\text { mortality } \\
(\mathbf{2 0 1 5} \text { \& 2016) }\end{array}$ & $\begin{array}{c}\text { All-cause } \\
\text { mortality at age } \\
\mathbf{6 5 + ( 2 0 1 5 ~ \& ~ 2 0 1 6 )}\end{array}$ & $\begin{array}{c}\text { CVD+R } \\
\text { mortality } \\
(\mathbf{2 0 1 5} \& \text { 2016) }\end{array}$ & $\begin{array}{c}\text { CVD+R in age } \\
\mathbf{6 5 + ( 2 0 1 5 ~ \& ~} \\
\mathbf{2 0 1 6})\end{array}$ \\
\hline Prague & $1,294,513$ & 18.8 & 6166 & 5179 & 3008 & 2752 \\
\hline Brno & 379,527 & 20.4 & 1934 & 1634 & 984 & 901 \\
\hline Ostrava & 290,450 & 19.5 & 1660 & 1279 & 837 & 736 \\
\hline Plzeň & 170,936 & 20.6 & 933 & 777 & 456 & 412 \\
\hline Liberec & 103,979 & 19.7 & 503 & 404 & 238 & 214 \\
\hline Olomouc & 100,494 & 19.9 & 490 & 405 & 219 & 203 \\
\hline České Budějovice & 93,863 & 20.4 & 498 & 397 & 235 & 208 \\
\hline Ústí nad Labem & 93,040 & 19.9 & 489 & 371 & 232 & 193 \\
\hline Hradec Králové & 92,917 & 23.3 & 463 & 396 & 243 & 225 \\
\hline Pardubice & 90,335 & 21.0 & 497 & 420 & 229 & 206 \\
\hline
\end{tabular}

Sources: CZSO 2019 (vdb.czso.cz) 
Table 2. Basic environmental characteristics of the cities studied

\begin{tabular}{|c|c|c|c|c|c|c|c|c|c|}
\hline \multirow{2}{*}{ City } & \multicolumn{5}{|c|}{ Proportion of city area with specific altitude [\%] } & \multicolumn{3}{|c|}{ City altitude } & \multirow{2}{*}{$\begin{array}{c}\text { Climate region } \\
\text { (Köppen } \\
\text { classification/national } \\
\text { classification)* }\end{array}$} \\
\hline & $<201$ & $201-250$ & $251-300$ & $301-350$ & $>350$ & $\min$ & $\max$ & ave & \\
\hline Praha & 8 & 22 & 43 & 27 & 0 & 175 & 399 & 274 & Cfb/warm \\
\hline Brno & 8 & 34 & 24 & 17 & 17 & 188 & 495 & 280 & $\mathrm{Cfb} /$ warm \\
\hline Ostrava & 1 & 72 & 25 & 1 & 0 & 196 & 337 & 237 & $\mathrm{Cfb} /$ warm \\
\hline Plzeň & 0 & 0 & 0 & 56 & 44 & 296 & 448 & 348 & $\mathrm{Cfb} /$ moderately warm \\
\hline Liberec & 0 & 0 & 0 & 4 & 96 & 307 & 978 & 469 & Cfb/moderately warm \\
\hline Olomouc & 0 & 74 & 12 & 5 & 9 & 206 & 435 & 245 & $\mathrm{Cfb} /$ warm \\
\hline České Budějovice & 0 & 0 & 0 & 0 & 100 & 375 & 557 & 411 & $\mathrm{Cfb} /$ moderately warm \\
\hline Ústí nad Labem & 33 & 22 & 16 & 12 & 17 & 129 & 646 & 259 & $\mathrm{Cfb} /$ warm \\
\hline Hradec Králové & 0 & 83 & 17 & 0 & 0 & 224 & 292 & 240 & Cfb/warm \\
\hline Pardubice & 0 & 100 & 0 & 0 & 0 & 210 & 256 & 224 & $\mathrm{Cfb} /$ warm \\
\hline
\end{tabular}

Sources: ArcČR 2016; authors' processing; *Based on national Quitt classification (Tolasz et al., 2007)

the deep valley of the River Elbe, partly intruding into the surrounding hills, with a warm climate. Ustí nad Labem is a shrinking city which the residential areas featuring sharp differences of social status and degree of affluence. Hradec Kralove and Pardubice, situated quite close to one another, lie in the flat terrain of the
River Elbe basin, with a warm climate. While Hradec Kralové is prospering, modern city with a historical urban core, Pardubice is far more industrialised. Average summer UHI intensity in Hradec Kralové is estimated at $2^{\circ} \mathrm{C}$, with a maximum of over $4^{\circ} \mathrm{C}$ (Středová et al., 2015; Rožnovský et al., 2017).

\section{Methodology}

\section{Temperature data}

Ten of the weather stations that are part of the Czech Hydrometeorological Institute (CHMI) network were used for temperature data acquisition. Most of these are located in the outskirts of the cities investigated. Their standards are aligned with those of the World Meteorological Organisation (WMO) (Table 3). Daily average temperature $\left(\mathrm{T}_{\mathrm{AVG}}\right)$, daily maximum temperature $\left(\mathrm{T}_{\mathrm{MAX}}\right)$ and daily minimum temperature $\left(\mathrm{T}_{\mathrm{MIN}}\right)$ were available for each of the stations. Further, mean series for the chosen Czech cities were calculated by averaging data from individual stations. These series were used in the spatial and temporal identification of heat-waves (see below), in a similar approach to that used by Kyselý and Huth (2004).

Two successive summer periods (July to August) 2015 and 2016 were selected. They differ substantially in terms of the courses of their seasonal temperatures. Summer 2015 was very hot - average temperature $\left(\mathrm{T}_{\mathrm{AVG}}\right)$ for the whole of Czechia was $19.2^{\circ} \mathrm{C}\left(2.2^{\circ} \mathrm{C}\right.$ above normal 1980-2010). $\mathrm{T}_{\mathrm{AVG}}$ for summer 2016 was $17.6^{\circ} \mathrm{C}$ (o. $6^{\circ} \mathrm{C}$ above normal). Although summer 2015 was

Table 3. Geographical characteristics of weather stations

\begin{tabular}{|l|c|c|c|c|}
\hline City, Area & WMO i.d. & Latitude & Longitude & Elevation (m) \\
\hline Prague, Libuš & 11520 & $50^{\circ} 00^{\prime} 28^{\prime \prime} \mathrm{N}$ & $14^{\circ} 26^{\prime} 49^{\prime \prime} \mathrm{E}$ & 302 \\
\hline Brno, Tuřany & 11723 & $49^{\circ} 09^{\prime} 11^{\prime \prime} \mathrm{N}$ & $16^{\circ} 41^{\prime} 20^{\prime \prime} \mathrm{E}$ & 241 \\
\hline Ostrava, Poruba & 11790 & $49^{\circ} 49^{\prime} 31^{\prime \prime} \mathrm{N}$ & $18^{\circ} 09^{\prime} 34 \mathrm{E} \mathrm{E}^{\prime \prime}$ & 239 \\
\hline Plzeň, Mikulka & 11450 & $49^{\circ} 45^{\prime} 54^{\prime \prime} \mathrm{N}$ & $13^{\circ} 22^{\prime} 43^{\prime \prime} \mathrm{E}$ & 360 \\
\hline Liberec & 11603 & $50^{\circ} 46^{\prime} 11^{\prime \prime} \mathrm{N}$ & $15^{\circ} 01^{\prime} 26^{\prime \prime} \mathrm{E}$ & 398 \\
\hline Olomouc, Holice & 11742 & $49^{\circ} 34^{\prime} 33^{\prime \prime} \mathrm{N}$ & $17^{\circ} 17^{\prime} 04^{\prime \prime} \mathrm{E}$ & 210 \\
\hline České Budějovice, Rožnov & 11546 & $48^{\circ} 57^{\prime} 07^{\prime \prime} \mathrm{N}$ & $14^{\circ} 28^{\prime} 17^{\prime \prime} \mathrm{E}$ & 394 \\
\hline Ústí nad Labem, Kočkov & 11502 & $50^{\circ} 41^{\prime} 02^{\prime \prime} \mathrm{N}$ & $14^{\circ} 02^{\prime} 28^{\prime \prime} \mathrm{E}$ & 375 \\
\hline Hradec Králové, Svobodné dvory & 11651 & $50^{\circ} 13^{\prime} 21^{\prime \prime} \mathrm{N}$ & $15^{\circ} 47^{\prime} 16^{\prime \prime} \mathrm{E}$ & 240 \\
\hline Pardubice, letiště & 11652 & $50^{\circ} 00^{\prime} 58^{\prime \prime} \mathrm{N}$ & $15^{\circ} 44^{\prime} 25 \mathrm{E}$ ' & 225 \\
\hline
\end{tabular}

Source: $\mathrm{CHMI}$ 
warmer overall, June 2015 TAVG $16.1^{\circ} \mathrm{C}$ (o. $3^{\circ} \mathrm{C}$ above normal), it was still cooler than June 2016 when $\mathrm{T}_{\mathrm{AVG}}$ was $17.2^{\circ} \mathrm{C}\left(1.4^{\circ} \mathrm{C}\right.$ above normal). $\mathrm{T}_{\mathrm{AVG}}$ for July 2015 was $20.2^{\circ} \mathrm{C}\left(2.4^{\circ} \mathrm{C}\right.$ above normal $)$ and $\mathrm{T}_{\mathrm{AVG}}$ for July 2016 was $18.6^{\circ} \mathrm{C}\left(0.8^{\circ} \mathrm{C}\right.$ above normal). It is relevant and worthy of note that August 2015 was extremely hot: $\mathrm{T}_{\mathrm{AVG}} 21.3^{\circ} \mathrm{C}$ (4. $0^{\circ} \mathrm{C}$ above normal), while $\mathrm{T}_{\mathrm{AVG}}$ in August 2016 was $17.0^{\circ} \mathrm{C}$ (o. $3^{\circ} \mathrm{C}$ below normal); $\mathrm{CHMI} \mathrm{XX}$.

\section{Identification of heat-waves}

There exists no universal definition of a heat-wave but, in general, a heat-wave consists of a number of consecutive days with temperatures high enough to cross certain thresholds. Such thresholds may be based on physiological or sociological factors related to local climate (Robinson 2001). In this study, the criteria applied by Huth et al. (2000) and Kyselý (2002) were employed to examine the impact of heat-waves on mortality. According to this approach, a heat-wave is defined as a continuous period during which: a) daily maximum temperature $\left(\mathrm{T}_{\mathrm{MAX}}\right)$ reaches at least $30^{\circ} \mathrm{C}$ for at least three days, $\mathrm{b}$ ) mean $\mathrm{T}_{\text {MAX }}$ over the whole period reaches at least $30^{\circ} \mathrm{C}$ and c) $\mathrm{T}_{\mathrm{MAX}}$ is not lower than $25^{\circ} \mathrm{C}$.

\section{Mortality data}

Data concerning mortality, containing the daily number of deaths for the summer months, (June-August)
2015 and 2016 was gathered, as well as for the two days (1st and 2nd) at the beginning of September (in order to allow for lag effects to be included in the analysis). All data were provided by Czech Statistical Office (CZSO). Analysis of all-cause and all-age mortality, as well as the elderly population (age 65 and over) as one of the groups most vulnerable to heat events, was undertaken Specific-cause mortality was observed in terms of both cardiovascular (Ioo-I99) and respiratory (Joo-J99) diseases (CVD+R). The mortality data was classified according to the International Statistical Classification of Diseases and Related Health Problems (Revision 10).

During the summer months of 2015 and 2016, 13,640 deaths were recorded in the areas investigated (Table 4). Analysis was performed by means of crude numbers, using 3-day accumulated mortality as well as mortality rate, the latter calculated per 1,00o inhabitants. The number of deaths was taken as the dependent variable. Using the non-parametric Mann-Whitney $U$ test, the compliance of distribution functions of deaths on heat-wave days and deaths on non-heatwave days was tested at the significance level of $\alpha=$ 0.05. In other words, the null hypothesis assumes that the medians of the number of deaths during heatwaves and beyond do not differ. The test was applied for all-cause mortality, CVD+R mortality and for analysis in the elderly population (age $65^{+}$).

\section{Results}

Before analysing the effects of heat-waves on mortality rate, it must be pointed out that there are substantial differences in total mortality among the cities investigated (Table 2). The highest mortality rate was observed in Ostrava (3.03) followed by Pardubice and Plzen (2.92), whereas the lowest mortality rates were observed in Prague and Liberec (2.59) followed by Olomouc (2.60). These figures imply a theoretical situation involving a lack of seasonality and an absence of daily oscillation in total mortality.

Higher total mortality rates during heat-waves compared with related seasonal averages are apparent in all the cities investigated. Specifically, the mortality rate during heat-wave periods was higher, in a range from 0.09 in Liberec to 0.61 in Pardubice and České Budějovice. The increase in mortality rate in heat-wave periods was more pronounced for the population aged $65+$. The results were ambiguous when the focus was tightened to mortality rate from cardiovascular and respiratory diseases (ICD10 codes) - lower mortality rates in this category were, surprisingly, detected in Plzeň, Liberec and Olomouc (Table 4).
More detailed analysis of mortality risk and mortality changes during the heat-wave periods was performed by comparing mortality on heat-wave days with other days. Within the two periods observed as independent samples, the Mann-Whitney $\mathrm{U}$ test was utilised, with chance alone set at less than 5\% (significance level $\mathrm{p}<0.05)$. Results for all-cause and all-age, as well as the over-65s, show statistically significant differences $(p<0.05)$ in mortality during heat-waves compared with other days in seven of the ten cities; however, the effect of heat-waves on mortality was statistically insignificant in Olomouc, Plzeň and Liberec (Table 5). Similar results were confirmed for CVD+R mortality, in total as well as in the elderly population. Results for Z-score suggest a statistically significant ( $p<0.05)$ level, of moderate or large effect, indicating a mortality increase during the heat-wave periods. For Olomouc, Plzeň and Liberec, changes in CVD+R mortality in all age groups, as well as the elderly population, were not statistically significant during and after heat-wave periods (Table 6).

The results presented analyse the effects of heat-waves on total mortality in 2015 and 2016 . However, it must be 
Table 4. Average mortality rates for 2015 and 2016 and mortality rates during heat-wave periods in 2015 and 2016

\begin{tabular}{|c|c|c|c|c|c|c|c|c|}
\hline \multirow{2}{*}{ City } & \multicolumn{2}{|c|}{ All-cause } & \multicolumn{2}{|c|}{ All-cause at age $65+$} & \multicolumn{2}{|c|}{$C V D+R$} & \multicolumn{2}{|c|}{ CVD+R at age $65+$} \\
\hline & Avg & HWs & Avg & HWs & Avg & HWs & Avg & HWs \\
\hline Prague & 2.59 & 2.95 & 11.79 & 13.55 & 1.26 & 1.44 & 6.26 & 7.14 \\
\hline Brno & 2.73 & 3.21 & 11.57 & 13.60 & 1.39 & 1.72 & 6.38 & 7.93 \\
\hline Ostrava & 3.03 & 3.54 & 12.54 & 14.68 & 1.53 & 1.69 & 7.21 & 7.96 \\
\hline Plzeň & 2.92 & 3.08 & 12.11 & 12.78 & 1.43 & 1.38 & 6.42 & 6.05 \\
\hline Liberec & 2.59 & 2.68 & 11.10 & 11.32 & 1.23 & 1.09 & 5.88 & 5.39 \\
\hline Olomouc & 2.60 & 2.70 & 11.33 & 11.52 & 1.16 & 1.02 & 5.68 & 5.26 \\
\hline České Budějovice & 2.83 & 3.44 & 11.58 & 13.31 & 1.34 & 1.75 & 6.07 & 7.82 \\
\hline Ústí nad Labem & 2.79 & 3.17 & 11.33 & 13.19 & 1.32 & 1.51 & 5.89 & 6.96 \\
\hline Hradec Králové & 2.65 & 3.23 & 10.12 & 12.47 & 1.39 & 2.02 & 5.75 & 8.17 \\
\hline Pardubice & 2.95 & 3.56 & 12.24 & 14.69 & 1.36 & 1.71 & 6.00 & 7.46 \\
\hline
\end{tabular}

HWs = heat-waves

Table 5. Results of statistical analysis for 3-day accumulated all-cause mortality during heat-wave days and other days (Independent Samples Mann-Whitney U Test)

\begin{tabular}{|l|c|c|c|c|c|c|}
\hline \multirow{2}{*}{ City } & \multicolumn{3}{|c|}{ All-cause mortality } & \multicolumn{3}{c|}{ All-cause mortality at age 65+ } \\
\cline { 2 - 7 } & $\mathrm{U}$ & Z-adjusted & $\mathrm{P}$-value & $\mathrm{U}$ & Z-adjusted & $\mathrm{P}$-value \\
\hline Prague & 946.5 & -7.12 & 0.00 & 920.0 & -7.21 & 0.00 \\
\hline Brno & 1337.5 & -5.88 & 0.00 & 1625.0 & -4.96 & 0.00 \\
\hline Ostrava & 1414.5 & -5.63 & 0.00 & 1578.0 & -5.11 & 0.00 \\
\hline Plzeň & 2739.5 & -1.39 & 0.16 & 2707.5 & -1.49 & 0.14 \\
\hline Liberec & 2815.0 & -1.15 & 0.25 & 2937.0 & -0.76 & 0.45 \\
\hline Olomouc & 2571.5 & -1.94 & 0.05 & 2745.5 & -1.38 & 0.17 \\
\hline České Budějovice & 1975.5 & -3.85 & 0.00 & 2273.5 & -2.89 & 0.00 \\
\hline Ústí nad Labem & 2087.5 & -3.49 & 0.00 & 2280.0 & -2.89 & 0.00 \\
\hline Hradec Králové & 1674.5 & -4.83 & 0.00 & 1910.5 & -4.07 & 0.00 \\
\hline Pardubice & 2038.5 & -3.65 & 0.00 & 2327.5 & -2.72 & 0.01 \\
\hline
\end{tabular}

Table 6. Results of statistical analysis for 3-day accumulated CVD+R mortality during heat-wave days and on other days (Independent Samples Mann-Whitney U Test)

\begin{tabular}{|l|c|c|c|c|c|c|}
\hline \multirow{2}{*}{ City } & \multicolumn{3}{|c|}{ CVD+R mortality } & \multicolumn{3}{c|}{ CVD+R at age 65+ } \\
\cline { 2 - 7 } & $U$ & Z-adjusted & P-value & $U$ & Z-adjusted & P-value \\
\hline Prague & 1447.0 & -5.52 & 0.00 & 1458.5 & -5.49 & 0.00 \\
\hline Brno & 1175.5 & -6.41 & 0.00 & 1299.5 & -6.02 & 0.00 \\
\hline Ostrava & 1979.5 & -3.83 & 0.00 & 2029.5 & -3.67 & 0.00 \\
\hline Plzeň & 3077.0 & 0.31 & 0.76 & 2984.5 & 0.61 & 0.54 \\
\hline Liberec & 2664.5 & 1.65 & 0.10 & 2834.5 & 1.10 & 0.27 \\
\hline Olomouc & 2993 & 0.59 & 0.56 & 3074.5 & 0.32 & 0.75 \\
\hline České Budějovice & 1997.0 & -3.80 & 0.00 & 2077.5 & -3.55 & 0.00 \\
\hline Ústí nad Labem & 2297.5 & -2.85 & 0.00 & 2345.5 & -2.70 & 0.01 \\
\hline Hradec Králové & 1843.0 & -4.30 & 0.00 & 1967.5 & -3.90 & 0.00 \\
\hline Pardubice & 1954.5 & -3.96 & 0.00 & 2211.0 & -3.14 & 0.00 \\
\hline
\end{tabular}

taken in into consideration that differences in temperature courses exist between the two summers, especially in terms of the ways in which the intensity and duration of the heat-waves are reflected in mortality. The average number of deaths, totalled over all the cities investigated for summer 2015 was 75 per day, compared with 71 per day in summer 2016. In summer 2015, when four heatwaves occurred, mortality depended on temperature $\left(\mathrm{R}^{2}\right.$ 
Table 7. Heat-wave periods in ten Czech cities, summers of 2015 and 2016

\begin{tabular}{|c|c|c|c|c|}
\hline Date & Duration (days) & $\operatorname{TMAX}\left({ }^{\circ} \mathrm{C}\right)$ & All-cause mortality & All-cause mortality/day \\
\hline $30.06 .-08.07 .2015$ & 9 & 35.0 & 800 & 89 \\
\hline $14.07 .-25.07 .2015$ & 11 & 36.2 & 830 & 76 \\
\hline $01.08 .-16.08 .2015$ & 16 & 37.1 & 1,394 & 87 \\
\hline $26.08 .-01.09 .2015$ & 7 & 34.3 & 559 & 78 \\
\hline $22.06-25.06 .2016$ & 4 & 33.3 & 313 & 80 \\
\hline
\end{tabular}

$=0.67$ for temperature and 3 -day accumulated mortality), while in 2016, when only one short heat-wave occurred, the relation between temperature and mortality was not significant. Altogether, in five recognised heat-waves, the average daily number of deaths stood at around 83 . The highest number of deaths per day (89) was observed in the first heat-wave of the season (30.06.-08.07. 2015). A high number of deaths per day (87) was also observed during the heat-wave with the highest TMAX (01.08.16.08.2015), (Table 7).

\section{Discussion}

This contribution demonstrates the impact of heatwaves on mortality in the summer seasons of 2015 and 2016 in ten Czech Cities. The results confirm a mortality increase during heat-waves, as described in previous studies of the region (Kyselý, 2004; Kyselý, 2009; Vyberčki et al., 2018; Graczyk et al., 2018). The statistical analysis herein disclosed significant increases in all-cause mortality during heat-waves in seven of the ten Czech cities investigated. The closest heat-wavemortality relationship was found in Prague, whereas in Plzeň, Olomouc and Liberec (all with populations bellow 200,000), no significant increase in mortality during heat-waves was detected.

Several explanations for these results present themselves. The low number of deaths in relatively small cities is one example, in that the more limited the data sample, the more sensitive it is in analysis; it is noteworthy that, as above, Olomouc and Liberec have generally low mortality rates. Further, the effects of UHI are less marked in smaller cities (Lehnert et al. 2018). Finally, it is highly unlikely that the socio-economic and demographic structures of populations are without influence. Beyond Czech borders, regional differences in mortality during heat-waves have been also been observed in Switzerland where, in summer 2003, an increase in all- mortality associated with heat occurred, with the highest impact among populations in Basel, Geneva and Lausanne, while no increase in mortality related to the temperature in Ticino was evident (Grize et al., 2005). In a study of four Italian cities, Michelozzi et al. (2005) also recorded the highest increase in excess mortality the north-western part of the country (Turin \& Milan) during the 2003 heatwave.

It becomes clear that further investigation, including longer periods and coverage of other social and health considerations (individual life-styles of, access to health care and level of urbanization among them) and their influences on mortality during heat-waves is urgently required. For example, Pascal et al. (2006) have demonstrated that excess mortality in French cites is not always related to temperature changes; their analysis shows rises in excess mortality during heat-waves in four out of the ten cities they investigated, while in the others no confirmed, clear link with temperature was evident. Nayak et al. (2018) have developed a heat vulnerability index, considering differences in regional socio-demographic and land-cover characteristics for New York State. Identified as the most vulnerable areas were: urban tracts with high housing density; areas with a high proportion of ageing populations; those with minority populations; and lower-income households.

The current study also looked into the impact of heat-waves on CVD+R-related mortality. Cardiovascular diseases are the leading cause of death in the Czech population, responsible for more than $50 \%$ of total mortality (Urban et al., 2016). Respiratory diseases are not among the leading causes of death, but are strongly influenced by the seasons and dependent on climate conditions and degree of urbanization (D'Amato et al., 2016). In this study, about $49 \%$ of all-cause deaths consisted of CVD+R mortality, which might imply that patterns in CVD+R mortality during heat events are contributing to oscillation in all-cause mortality. However, our results appear to indicate that increases in $\mathrm{CVD}+\mathrm{R}$ mortality during heat-waves were ambiguous in some cities. To date, only a few studies have explored cardiovascular mortality in relation to hot periods in the region. Urban et al. (2016) investigated impacts of heat events on cardiovascular mortality in the Czech population and found that the most marked relative deviation in mortality during summer days occurred when the mean 
daily temperature exceeded the 9oth percentile. Further studies employing larger datasets are required.

Exacerbation of mortality of the elderly population (65+) during heat-wave periods was also recognized in this study, both for all-cause and for CVD+R mortality. The majority of all deaths (about $83 \%$ ), as well as CVD-R mortality (91\%), consisted of people aged 65 and over, which implies that deviations in mortality within the elderly population may be responsible for patterns in total mortality, and particularly in $\mathrm{CVD}+\mathrm{R}$ mortality. This is in agreement with the results of most of the studies conducted after the 2003 heat-wave. Differences from region to region, and in levels of increase in excess mortality during heatwaves, exhibit considerable variation, but marked increases in temperature-related mortality with age have been confirmed in several countries (Grize at al., 2005; Michelozzi et al., 2005; Basu, 2009; Djurdjev et al., 2012; Nayak et al., 2018). As life-expectancy is projected to lengthen in the future, the relative numbers of older people in the population will rise, leading to further increases in all chronic diseases. All developed countries have high crude death rates for the over-65s, and the elderly are among the most vulnerable to temperature extremes. However, a significant number of premature deaths in old age could be avoided by changes in public health policies, especially those related to mitigation and adaptation.

Considering increased mortality during heatwaves and the fact that the frequency and intensity of heat-waves (Forzieri et al., 2017; Lhotka et al., 2018), as well as hot days and warm nights (Geletič et al., 2019), are expected to rise in the central European region, cities and their inhabitants will have to adapt to such events. Evidence derived from global predictability of extreme temperature events suggests that vulnerability should be measured in terms of local mortality and morbidity data.

Some lessons may be learned from the experience of other countries. For example, after 2003 (in which a heat-wave was responsible for nearly 15,000 deaths in France), the French government identified key issues, including a complete absence of any intervention plan in the event of a heat-wave, and also a lack of coordination between the social services and health providers (Kovats \& Hajat 2008). In order to decrease the hazard level for temperature-related mortality, some countries have started to develop heat health action plans (HHAP) and heat health warning systems (HHWS). As support, the World Health Organization, in collaboration with the World Meteorological Organization, has published guidelines on warning-system development, with the primary objective of providing a framework within which to identify and upgrade understanding of general heat-health problems in such a way that authorities can employ it for HHAP and HHWS (WMO and WHO 2015). Indeed, some studies from the beginning of the 21st century have recognized a decrease in the impacts of heat events on population health and mortality resulting from improvements in public health systems and living conditions (Carson et al., 2006; Sheridan et al., 2009) Despite such changes in administrative sensitivity to heat events and adaptation, heat-wave hazard is an important challenge to any population, particularly to people living in cities. Prevention of premature mortality arising out of heat-waves is now a pressing issue of public health concern (Kovats \& Hajat 2008).

\section{Conclusion}

Our findings suggest that heat-waves are important hazards to the population. Analysis revealed that mortality increases with intensity (maximum temperature) of heat-waves, which suggests that urban populations are not completely adapted to extreme heat events. The results herein tally with other investigation conducted in regions with temperate climates and could be used as groundwork for more comprehensive and advanced research, covering further social and health features (individual life-styles, access to health care, and level of urbanization among them) and their association with premature mortality during heat-waves.

The main contribution to this research is provided by observed populations, since the analysis was conducted in selected urban areas in Czechia (ten cities). It is well known that urban populations are more vulnerable during heat-waves, especially the elderly and people with chronic diseases. It must be borne in mind, therefore, that analyses based on the entire population (urban and rural) of the country might well lead to dilution of data and misleading results.

In order to detect the intensity and hazard level of heat-waves, future research should focus on the following: a) coverage of extended periods; b) comparison with rural areas; $c$ ) investigation of heat-wave impacts on mortality in the largest cities, conducted on an intra-urban basis. 


\section{Acknowledgements}

The authors of this paper would like to extend their gratitude to the ERASMUS+ Programme, considering the fact that this research was initiated thanks to the KA107 mobility programme between Palacký University, Olomouc and University of Novi Sad.

\section{References}

Ballester, J., Rodó, X., \& Giorgi, F. (2010). Future changes in Central Europe heat waves expected to mostly follow summer mean warming. Climate $d y$ namics, 35(7-8), 1191-1205. DOI: 10.1007/soo382-0090641-5

Basu R. (2009). High ambient temperature and mortality: a review of epidemiological studies from 2001 to 2008. Environmental Health, 8(1), 40-52. doi: 10.1186/1476-069X-8-40

Bogdanović, D.C., Milošević, Z.G., Lazarević, K.K., Dolićanin, Z.C., Randelović, D.M., \& Bogdanović, S.D. (2013). The impact of the July 2007 heat wave on daily mortality in Belgrade, Serbia. Central European Journal of Public Health, 21(3), 140-145.

Bobvos, J., Fazekas, B. \& Paldy, A. (2015). Assessment of heat-related mortality in Budapest from 2000 to 2010 by different indicators. Idojaras, 119(2), 143-158.

Bobvos, J., Malnasi, T., Rudnai, T., Cserbik, D. \& Paldy, A. (2017). The effect of climate change on heat-related excess mortality in Hungary at different area levels. Idojaras, 121(1), 43-62.

Carson, C., Hajat, S., Armstrong, B., \& Wilkinson, P. (2006). Declining vulnerability to temperaturerelated mortality in London over the 2oth century. American Journal of Epidemiology, 164(1), 77-84. doi.org/10.1093/aje/kwj147

Christidis, N., Jones, G. S., \& Stott, P. A. (2015). Dramatically increasing chance of extremely hot summers since the 2003 European heatwave. Nature Climate Change, 5(1), 46-50. DOI: 10.1038/nclimate2468

D’Amato, G., Pawankar, R., Vitale, C., Lanza, M., Molino, M., Stanziola, A., Sanduzzi, A., Vatrella, A., D'Amato, M. (2016). Climate Change and Air Pollution: Effects on Respiratory Allergy. Allergy Asthma Immunology Research, 8(5), 391-395. doi: 10.4168/ aair.2016.8.5.391

D'Ippoliti, D., Michelozzi, P., Marino, C., de Donato, F., Menne, B., Katsouyanni, K., Kirchmayer, U., analitis, A., Medina-Ramon, M., Paldy, A., Atkinson, R., Kovats, S., Bisanti, L., Schneider, A., Lefranc, A., Inguez, C., \& Perucci, C. (2010). The impact of heat waves on mortality in 9 European cities: results from the EuroHEAT project. Environmental Health. doi.org/10.1186/1476-069X-9-37
De Perez, E.C., Van Alast, M., Bischiniotis, K., Mason, S., Nissan, H., Pappenberger, F., Stephens, E., Zsoter, E., \& Van den Hurk, B. (2018). Global predictibility of temperature extremes. Environmental Research Letter, 13, doi.org/10.1088/1748-9326/aab94a.

Djurdjev, B., Arsenović D., \& Savić, S. (2012). Temperature-Related Mortality in Belgrade in the Period 1888-2008. Acta Geographica Slovenica, 52(2). 385-395.

EEA (2017). Climate change, impacts and vulnerability in Europe 2016. An indicator-based report. Luxembourg.

Fouillet, A., Rey, G., Laurent, F., Pavillon, G., Bellec, S., Guihenneuc-Jouyhaux, C., Clavel, J.,Jougla, E., \& Hemon, D. (2006). Excess mortality related to the August 2003 heat wave in France. Internacional archives of occupational and environmental health, 80 (1), 16-24. DOI 10.1007/soo420-006-0089-4

Forzieri, G., Cescatti, A., e Silva, F. B., \& Feyen, L. (2017). Increasing risk over time of weather-related hazards to the European population: a data-driven prognostic study. The Lancet Planetary Health, 1(5), e20o-e208.DOI:10.1016/S2542-5196(17)30082-7

Graczyk, D., Kundzewicz, Z. W., Choryński, A., Førland, E. J., Pińskwar, I., \& Szwed, M. (2019). Heatrelated mortality during hot summers in Polish cities. Theoretical and Applied Climatology, 136(3-4), 1259-1273. doi.org/10.1007/s00704-018-2554-x

Grize, L., Huss, A., Thommen, O., Schindler, C., \& Braun-Fahrlander, C. (2005). Heat wave 2003 and mortality in Switzerland. Swiss Medical Weekly, 135(13-14), 200-205. DOI: 2005/13/smw-11009

Huang, C., Barnett, A. G., Wang, X., Vaneckova, P., FitzGerald, G., \& Tong, S. (2011). Projecting future heat-related mortality under climate change scenarios: a systematic review. Environmental health perspectives, 119(12), 1681-169o. DOI: 10.1289/ ehp. 1103456

Huth, R., Kyselý, J., \& Pokorná, L. (2000). A GCM simulation of heat waves, dry spells, and their relationships to circulation. Climatic Change, 46(1-2), 29-60. doi.org/10.1023/A:1005633925903

Hutter, H.P., Moshammer, H., Wallner, P., Leitner, B., Kundi, M. (2007): Heatwaves in Vienna: effects on mortality. Wiener Klinische Wochenschrift, 119(7-8), 223-227. doi.org/10.1007/s00508-006-0742-7 
IPCC. Summary for Policymakers. In Climate Change 2014: Impacts, Adaptation, and Vulnerability. Part A: Global and Sectoral Aspects. Contribution of Working Group II to the Fifth Assessment Report of the Intergovernmental Panel on Climate Change; Field, C.B., Barros, V.R., Dokken, D.J., Mach, K.J., Mastrandrea, M.D., Bilir, T.E., Chatterjee, M., Ebi, K.L., Estrada, Y.O., Genova, R.C., et al, Eds.; Cambridge University Press: Cambridge, UK; New York, NY, USA, 2014; pp. 1-32.

Kovats S. \& Hajat S. (2008). Heat Stress and Public Health: A Critical Review. Annual Review of Public Health, 29, 41-55. Doi.org/10.1146/annurev.pubhealth.29.020907.090843

Kopp, J., Frajer, J., \& Pavelková, R. (2015). Driving forces of the development of suburban landscape - A case study of the Sulkov site west of Pilsen. Quaestiones Geographicae, 34(3), 51-64. doi.org/10.1515/ quageo-2015-0028

Kyselý, J. (2002). Temporal fluctuations in heat waves at Prague-Klementinum, the Czech Republic, from 1901-1997, and their relationship to atmospheric circulation. International Journal of Climatology, 22, 33-50. DOI: 10.1002/joc.720

Kyselý, J. (2003). Časová proměnlivost horkých vln v ČR a extrémní horká vlna z roku 1994. Meteorologické zprávy, 56, 13-19.

Kysely, J., \& Huth, R. (2004). Heat-related mortality in the Czech Republic examined through synoptic and traditional approaches. Climate research, 25(3), 265-274. DOI: $10.3354 / \mathrm{cro} 25265$

Kysely, J., Pokorna, L., Kyncl, J., \& Kriz, B. (2009). Excess cardiovascular mortality associated with cold spells in the Czech Republic. BMC public health, 9(1), 19. doi:10.1186/1471-2458-9-19

Le Tertre, A., Lefranc, A., Eilstein, D., Declercq, C., Medina, S., Blanchard, M., Chardon, B., Fabre, P., Filleul, L., Jusot, J.F., \& Pascal, L. (2006). Impact of the 2003 heatwave on all-cause mortality in 9 French cities. Epidemiology, 75-79. DOI: 10.1097/01. ede.0000187650.36636.1f

Li, T., Ban, J., Horton, R. M., Bader, D. A., Huang, G., Sun, Q., \& Kinney, P. L. (2015). Heat-related mortality projections for cardiovascular and respiratory disease under the changing climate in Beijing, China. Scientific reports, 5, 11441. DOi: 10.1038/srep11441

Lhotka, O., Kyselý, J., \& Farda, A. (2018). Climate change scenarios of heat waves in Central Europe and their uncertainties. Theoretical and applied climatology, 131(3-4), 1043-1054. DOI 10.1007/so0704016-2031-3

Michelozzi, P., De Donato, F., Bisanti, L., Russo, A., Cadum, E., DeMaria, M., D Ovidio, M., Costa, G., \& Perucci, CA. (2005). The impact of the summer
2003 heat wave on mortality in four Italian cities. Eurosurveillance, 10(7-9), 161-164.

Nayak, S.G., Shrestha, S., Kinney, P.L., Ross Z., Sheridan S.C., Plantea C.I., Hsu W.H., Muscatello N., \& Hwang S.A. (2018). Development of a heat vulnerability index for New York State. Public Health, 161, 127-137. doi.org/10.1016/j.puhe.2017.09.006

Paci, D. (2014). Human Health Impacts of Climate Change in Europe. Report for the PESETA II project. JRC. European Commission, Luxembourg.

Pascal, M., Laaidi, K., Ledrans, M., Baffert, E., Caserio-Schonemann, C., Le Tertre, A., Manach J., Medina, S., Rudant, J., \& Empereur-Bissonnet, P. (2006). France's heat health watch warning system. International Journal of Biometeorology, 50, 144-153. DOI 10.1007/s00484-005-0003-x

Robine, J. M., Cheung, S. L. K., Le Roy, S., Van Oyen, H., Griffiths, C., Michel, J. P., \& Herrmann, F. R. (2008). Death toll exceeded 70,00o in Europe during the summer of 2003. Comptes rendus biologies, 331(2), 171-178. doi:10.1016/j.crvi.2007.12.001

Robinson, P. J. (2001). On the definition of a heat wave. Journal of applied Meteorology, 40(4), 762-775. doi.org/10.1175/1520-0450(2001)040\%3C0762:OTD OAH\%3E2.o.CO;2

Rožnovský, J., Litschmann, T., Středová, H., Středa, T., Salaš, P., \& Horká, M. (2017). Microclimate Evaluation of the Hradec Králové City using HUMIDEX. Contributions to Geophysics and Geodesy, 47(3), 231246. DOI: 10.1515/congeo-2017-0012

Sheridan, S. C., Kalkstein, A. J., \& Kalkstein, L. S. (2009). Trends in heat-related mortality in the United States, 1975-2004. Natural Hazards, 50(1), 145-16o. DOI:10.1007/s11069-008-9327-2

Středová, H., Středa, T., \& Litschmann, T. (2015). Smart tools of urban climate evaluation for smart spatial planning. Moravian geographical reports, 23(3), 47-57. doi.org/10.1515/mgr-2015-0017

Tolasz, R., Míková, T., Valeriánová, A., \& Voženílek, V. (2007). Atlas podnebí Česka. Prague: ČHMÚ, UPOL.

Urban, A., Burkart, K., Kysely, J., Schuster, C., Plavcova, E., Hanzlikova, H., Štepanek, P., \& Lakes T. (2016). Spatial Patterns of Heat-Related Cardiovascular Mortality in the Czech Republic. International Journal of Environmental Research and Public Health. doi:10.339o/ijerph13030284

Urban, A., \& Kysley, J. (2014). Comparison of UTCI with other thermal indices in the assessment of heat and cold effects on cardiovascular mortality in the Czech Republic. International Journal of Environmental Research and Public Health. doi:10.3390/ ijerph110100952

Urban, A, Hondula, D. M., Hanzlíková, H., Kyselý, J., (2019). The predictability of heat-related mortality in Prague, Czech Republic, during summer 2015 - 
a comparison of selected thermal indices. International Journal of Biometeorology, 63(4), 535-548. doi: 10.1007/s00484-019-01684-3

Vyberčki, D., Švec, M., Faško, P., Savinova, H., Trizna, M., \& Mičietova E. (2015). The effects of the 19962012 summer heat events on human mortality in Slovakia. Moravian Geographical Reports, 23(3), 5870. doi.org/10.1515/mgr-2015-0018

Vyberčki, D., Labudova, L., Eštokova, M., Faško, P., \& Trizna M. (2018). Human mortality impacts of the 2015 summer heat spells in Slovakia. Theoretical Applied Climatology, 133, 925-936. DOI 10.1007/ s00704-017-2224-4

Vysoudil, M., Lehnert, M., \& Kladivo, P. (2016). Heat stress in the urban and suburban landscape and its spatial differentiation through the example of a medium-sized city. Dela, 46, 163-182.

Vandentorren, S., Suzan F., Medina, S., Pascal M., Maulpoix, A., Choen, JK., \& Ledrans, M. (2004). Mortality in 13 French Cities during the August 2003 Heat Wave. American Journal of Public Health, 94(9), 1518-1520.

WMO \& WHO (2015). Heatwaves and Health: Guidance on Warning-System Development. Geneva.<smiles>C=CC</smiles>

Internet 1: CHMI XX: http://portal.chmi.cz/historicka-data/pocasi/uzemni-teploty

Internet2: CHMI: portal.chmi.cz/files/portal/docs/ meteo/om/weather_links/Pocasi/Klimat_stanice. xls 